\title{
Preliminary data on the effect of semi-synthetic baits for Noctuidae (Lepidoptera) on the non-target Lepidoptera species
}

\author{
Antal Nagy ${ }^{1}$ - István Szarukán ${ }^{1}$ - Ferenc Gém ${ }^{1}$ - Rita Nyitrai ${ }^{1}$ - Bence Füsti-Molnár ${ }^{1}$ - Attila Némerth ${ }^{1}$ - \\ Lajos Kozák ${ }^{2}$ - Attila Molnár ${ }^{3}$ - Krisztián Katona ${ }^{4}$ - Szabolcs Szanyi ${ }^{5}$ - Zoltán Varga ${ }^{5}$ - Miklós Tóth ${ }^{6}$ \\ ${ }^{1}$ Institute of Plant Protection, University of Debrecen, Hungary \\ ${ }^{2}$ Department of Nature Conservation Zoology and Game Management, University of Debrecen, Hungary \\ ${ }^{3}$ Department of Biology and Chemistry, Ferenc Rákóczi II. Transcarpathian Hungarian Institute, Beregszász, Ukraine \\ ${ }^{4}$ Faculty of Biology, Uzhhorod National University, Uzhhorod, Ukraine \\ ${ }^{5}$ Department of Evolutionary Zoology, University of Debrecen, Hungary \\ ${ }^{6}$ Plant Protection Institute, CAR HAS, Budapest, Hungary \\ nagyanti@agr.unideb.hu
}

SUMMARY

\begin{abstract}
Noctuidae are one of the most important Lepidoptera groups containing dangerous pest species. Monitoring and detection of these pest species is routinely performed by traps baited with sex-pheromones. Baits that attract both males and females were developed for improved pest management. First the effectiveness of different synthetic compounds was evaluated. We also tested semi-synthetic baits that contained both synthetic and natural components (wine and beer). These were more attractive for moths considering species richness and abundance. Disadvantage of this increased effectiveness is that the traps catch more non target, rare and even protected species. In this study we analysed the effect of semi-synthetic baits developed for Noctuid moths containing wine on other non-target Lepidopterans. In the six sampling sites traps caught 17158 individuals of 183 Lepidoptera species. The number of Noctuidae species was 124, while their proportion was $84.4 \%$. The traps caught 813 individuals of 9 protected and 20 valuable species, which was only $4.7 \%$ of all Lepidopterans. In contrast the mean proportion of 33 dangerous and potential pest species was 31.3\% (5375 individuals). Number and abundance of both protected and pest species were affected by landscape structure. The risks of catching non-target species was higher in species rich natural and seminatural landscape. In homogenous arable lands the number and proportion of valuable Lepidopterans was not significant.
\end{abstract}

Keywords: pest monitoring, food attractants, loss of biodiversity, semi-synthetic baits

\section{INTRODUCTION}

Noctuidae is one of the most important families of Lepidoptera because of several dangerous and economically important pest species. The monitoring of these pests, which is an important part of the IPM (Integrated Pest Management) strategy against them, is generally performed by different trapping methods. In the last decades, widely used sex pheromone-baited traps have replaced the light traps used before. These baited traps can easily be used and are very effective and species specific, but lure only male moths. However, data of females are more valuable for pest control decisions, so the development of female catching baits have been ongoing since the 1970's (Creighton et al., 1973; Cantelo and Jacobson, 1979; Landolt, 2000; Landolt and Alfaro, 2001; Tóth et al., 2010). The effectiveness of several synthetic compounds (e.g. phenylacetaldehyde, isoamyl-alcohol and isobutanol in combination with acetic acid) were proved to be effective for Noctuid moths. The effectiveness of these synthetic baits can be increased with wine and beer as natural additives. These 'semisynthetic' baits lure more species and more individuals than the synthetic ones (Nagy et al., 2014; Tóth et al., 2015). These synthetic and semi-synthetic baits are more general attractants than species specific pheromones. Using these traps, several important pest species can be monitored in the same time minimizing sampling effort (Tóth et al., 2010). The remarkable disadvantage of the lack of specificity is the risk of catching non-target and even rare or protected species. In some cases, even the more specific traps baited with sex pheromone can also catch non target species (Olenici et al., 2007), but the probability of non-target catches might be much higher in case of traps baited with feeding attractants.

In the present study, the effect of semi-synthetic baits, consisting of isoamyl alcohol, acetic acid and wine, was analysed on the non-pest, non-target Lepidoptera species. We used data from different studies, which aimed to develop 'bisex' (attractive for both males and females) baits or faunistic analysis of natural and semi-natural habitats. Our goal was to determine the amount of the non-target effect and provide a basis for further investigations. 


\section{MATERIAL AND METHODS}

In the present analysis we used data of different studies on semi-synthetic baits for trapping Noctuid pest species. The sampling was carried out in six locations in East and Northeast Hungary (5 sites) and West Ukraine (1 site) during 2013-2014. Four of the sampling sites (Forró, Balmazújváros, Debrecen-Ondód, Hernádnémeti) were located in mostly agricultural landscape surrounded by intensively used arable lands while the others (Nagycsere and Nagydobrony) were surrounded with more diverse extensively used landscapes (Figure 1, Table 1).

Figure 1: Location of the sampling sites and linear transects of the traps in the six studied sites in 2013-2014 (Surce: GoogleEarth).

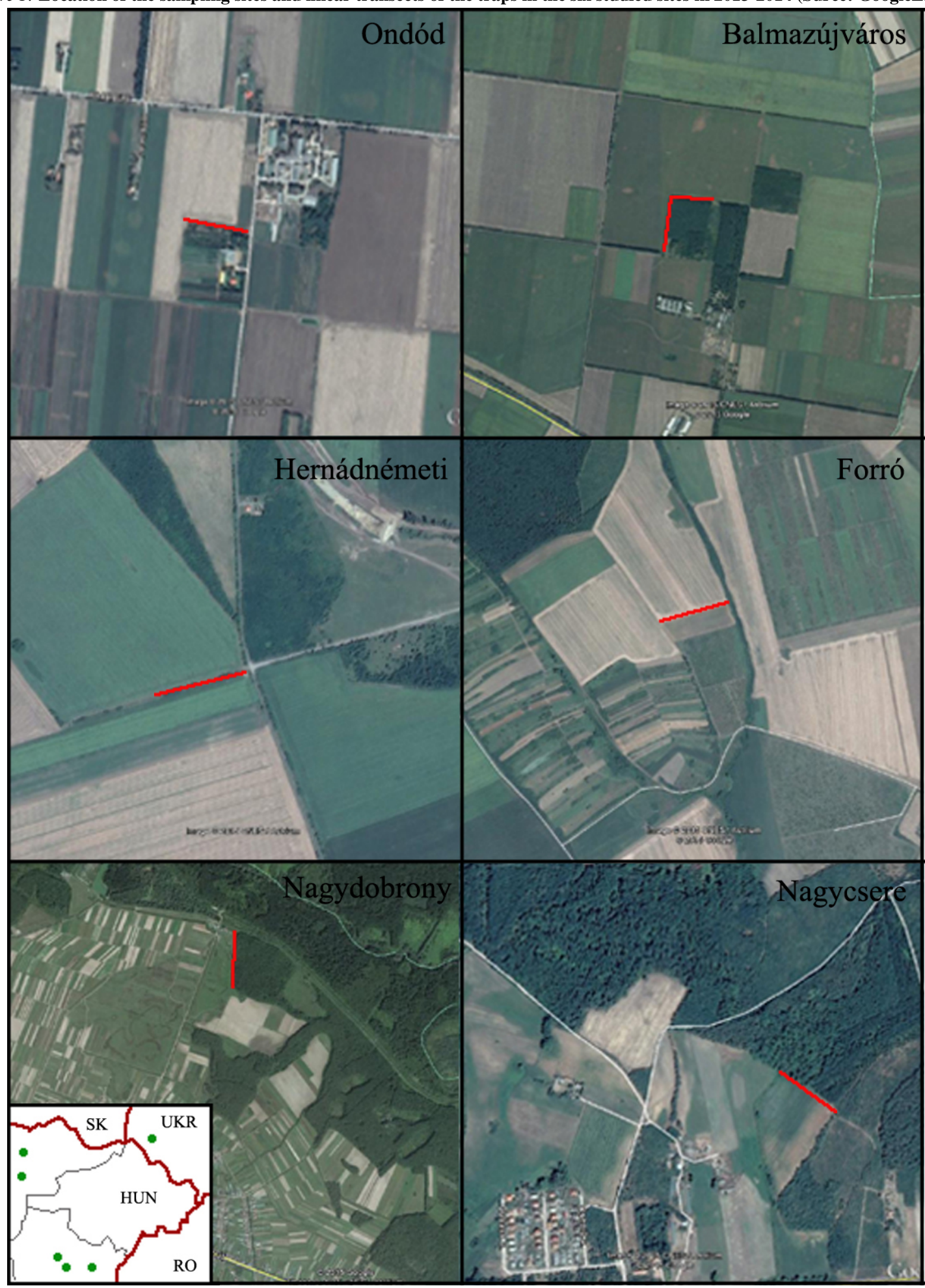




\begin{tabular}{|c|c|c|c|c|}
\hline Sampling area & $\mathbf{N}$ & $\mathbf{E}$ & Start & Finish \\
\hline Forró & $47^{\circ} 19.770^{\prime}$ & $21^{\circ} 3.773^{\prime}$ & $1^{\text {st }}$ July 2013 & $1^{\text {st }}$ November 2013 \\
\hline Debrecen-Ondód & $47^{\circ} 32.031$ ' & $21^{\circ} 31.053$ & $2^{\text {nd }}$ July 2013 & $2^{\text {nd }}$ November 2013 \\
\hline Nagydobrony & $48^{\circ} 25.619^{\prime}$ & $22^{\circ} 25.128^{\prime}$ & $20^{\text {th }}$ July 2014 & $19^{\text {th }}$ October 2014 \\
\hline Nagycsere & $47^{\circ} 31.847^{\prime}$ & $21^{\circ} 46.910^{\prime}$ & $17^{\text {th }}$ July 2014 & $12^{\text {th }}$ November 2014 \\
\hline Hernádnémeti & $48^{\circ} 9.595^{\prime}$ & $21^{\circ} 2.991^{\prime}$ & $2^{\text {nd }}$ July 2014 & $16^{\text {th }}$ November 2014 \\
\hline Balmazújváros & $47^{\circ} 36.202^{\prime}$ & $21^{\circ} 26.352^{\prime}$ & $8^{\text {th }}$ July 2014 & $22^{\text {nd }}$ November 2014 \\
\hline
\end{tabular}

In Forró, Ondód, Hernádnémeti and Balmazújváros the effect of natural compounds (wine and beer) and their extracts on the efficiency of synthetic lures was tested. In Nagycsere the Noctuidae fauna of a semi-natural landscape, while in Nagydobrony the fauna of the protected Nagydobrony Game Reserve was studied using synthetic and semi-synthetic baits for Noctuid species. We use the data collected by semi-synthetic baits contain mixture of isoamyl alcohol, acetic acid and red wine (1:1:1, $3 \mathrm{ml})$, which was used in all of the six studies. Polypropylene tubes with $4 \mathrm{ml}$ capacity were used as dispensers (Tóth et al., 2015). The mixture was administered on dental rolls inside the tubes. The lure could evaporate across a small opening with $4 \mathrm{~mm}$ in diameter, which was opened when setting out in the field. The trapped moths were killed by an insecticide strip.

During the studies CSALOMON ${ }^{\circledR}$ VarL+ traps were used in five (Balmazújváros, Ondód, Hernádnémeti and Forró) or four (Nagydobrony, Nagycsere) repetitions. The traps were placed in the sites on trees situated in the edge of the sites in 1.8-2 m height. The distance between the traps was 40-100 m depending on the design of the given study. The samplings were mostly carried out between July and November in 2013 and 2014 (Table 1). The traps were emptied twice a week (Forró, Ondód, Balmazújváros and Hernádnémeti) or weekly (in the faunistic studies in Nagycsere and Nagydobrony). The baits were changed in every four weeks. The collected material was deep-frozen and stored until identification. The sampled individuals were identified according the works of Kádár et al. (2010), Mészáros and Szabóky (2012) and Varga (2011). For the nomenclature and characterization of species, the book „Magyarország Nagylepkéi” (Varga, 2011) were used.

For characterization of the sampled material total number of species and individuals, number of species and individuals per site and their means per trap was used. These variables were also tallied by families especially for Noctuidae. In order to characterize and assess the effect of the semi-synthetic baits on non-target Lepidoptera species the groups of pest and vulnerable (protected and/or faunistically interesting) species were also characterized with total and mean number of species and individuals in case of groups, families and species. The conservation value of the species was established on the basis of KÖM (2001). The group of pest species was established on the basis of Jermy and Balázs 1993, Szabóky and Leskó (1999) and Tóth (1999).

\section{RESULTS AND DISCUSSION}

In the six sampling sites the traps caught 17642 Lepidoptera that belonged to 184 species and nine families (see Appendix 1). The $2.7 \%(n=484)$ of the specimens could be identified only at the family level. In case of Hepialidae only one specimen was caught that also could not be identified at species level (Table 2). Beyond that 843 individuals of Vespidae species (Vespa crabro, V. germanica and Polistes sp.) and 11 honey-bees (Apis mellifera) were sampled.

The most species rich sites were Nagycsere (128) and Nagydobrony (91), which can be characterised by most diverse landscape structure than the others, where the species number ranged between 57 and 70 . The mean number of species per trap was higher in Nagycsere $(71.3 \pm 7.1)$ while in Ondód a trap lured only $33.2( \pm 5.5)$ species on the average. The abundance of Lepidoptera generally was higher in the less diverse arable lands. The mean number of individuals per trap was the highest in Balmazújváros $(1162 \pm 127.1)$, however the abundance

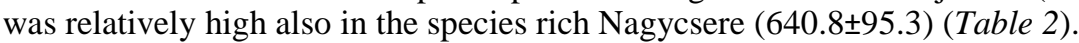

The semi-synthetic bait used in these samplings was developed to monitor noctuid pest species. In the six sites 126 Noctuidae species of 17 subfamilies were sampled, which were $68.9 \%$ of all sampled Lepidoptera. The ratio of Noctuidae species among all sampled Lepidoptera was higher (82.9-90.6\%) in the less diverse agroecosystems than in the most diverse extensively used landscapes (67.2-72.5\%). The total number of Noctuid moths was 14487 that was the $84.4 \%$ of the identified Lepidopterans and their ratio varied between $70.2-95.5$ by sites. The baits showed much higher effectiveness in case of species belonging to Xyleninae, Noctuinae, Hadeninae and Acronictinae subfamilies, which cumulative ratio was 80.4\% (11653 individuals) among sampled Noctuidae moths (Table 2). 
The characteristic variables of samples taken in the six studied sites in 2013-2014. N: number of individuals, Ntrap: mean number of individuals per trap [individuals/trap], S: number of species, Strap: mean number of species by trap [species/trap], SD: standard

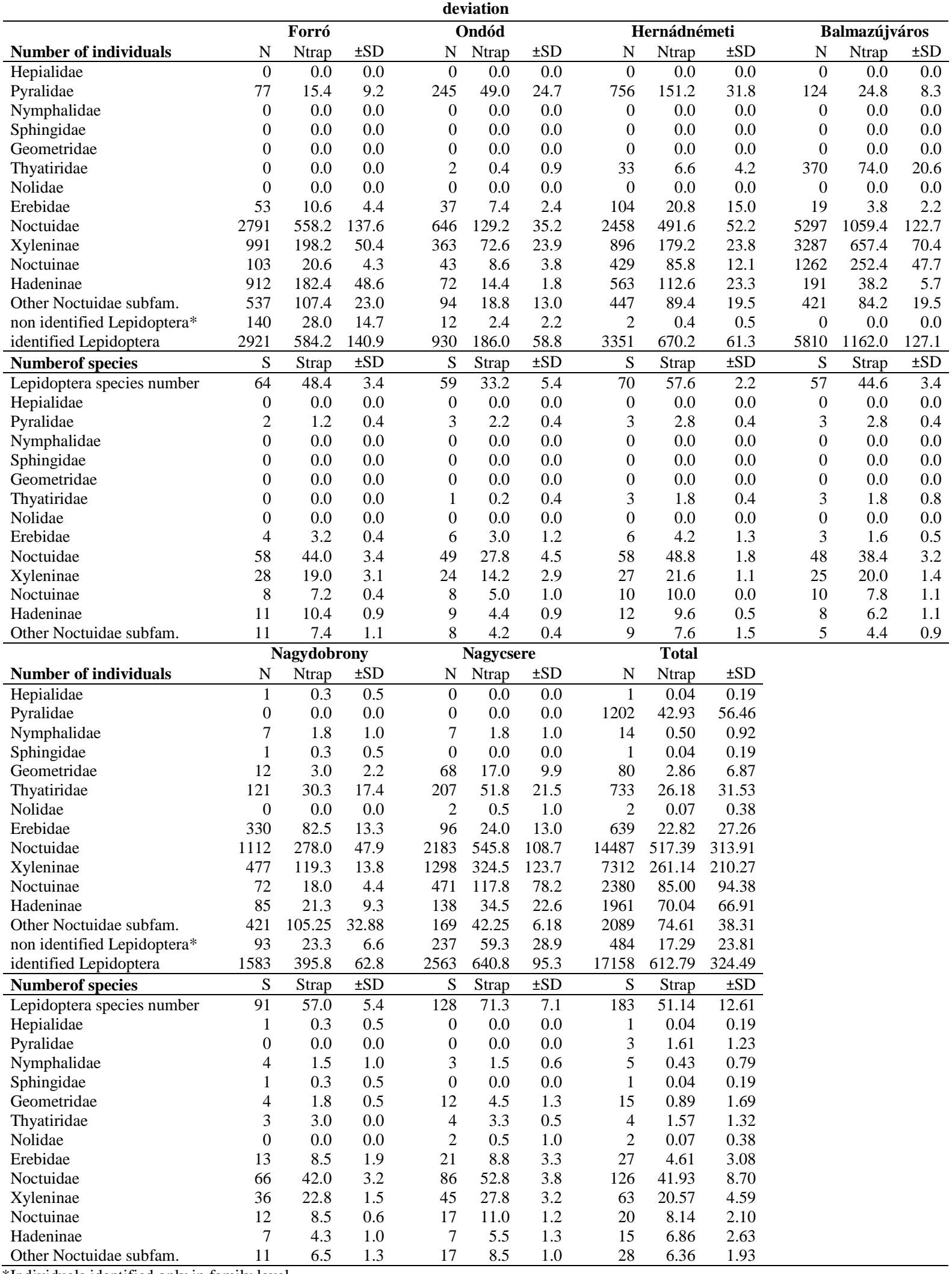

*Individuals identified only in family level.

In Forró all the five most abundant species, in Ondód, Hernádnémeti and Balmazújváros four, while Nagycsere and Nagydobrony three of them were Noctuid moths. Beyond them the baits lured high number of Hypsopygia costalis (Pyralidae), Pelosia muscerda (Erebidae) and two Thyatiridae species (Tethea ocularis and Thyatria batis). The most abundant species of the sites are mostly occurred in all sites, but the locally dominant 
Pelosia muscerda, Cirrhia icterica and Craniophora ligustri occurred only in two sites with higher habitat diversity (Nagycsere and Nagydobrony). The common and polyphagous Agrochola circellaris, Mythimna albipuncta, Xestia xanthographa and Acronicta rumicis were dominant in three sites. The also widely distributed Cirrhia ocellaris, Hypsopygia costalis, Allophyes oxyacanthae, Trachea atriplicis, Tethea ocularis and Agrotis segetum reached high relative frequencies in two whereas the others only in one site (Table 3). Most of these species feed on tree canopy and only 6 of them can be regarded as real or potential pest species. Among them only Agrotis segetum, which can cause significant damage in most crops and even in horticulture, is a harmful pest.

Table 3

Five most abundant species of the studied sites with their relative frequencies [RF\%] and number of occupied sites. The species are ordered decreasingly by their summarised RF\%

\begin{tabular}{|c|c|c|c|c|c|c|c|c|}
\hline & Forró & Ondód & $\begin{array}{c}\text { Hernád- } \\
\text { németi }\end{array}$ & $\begin{array}{l}\text { Balmaz- } \\
\text { újváros }\end{array}$ & $\begin{array}{c}\text { Nagy- } \\
\text { dobrony }\end{array}$ & $\begin{array}{l}\text { Nagy- } \\
\text { csere }\end{array}$ & Sum & $\begin{array}{c}\text { site } \\
(n=6)\end{array}$ \\
\hline Cirrhia ocellaris & & & & 30.31 & & 7.062 & 11.70 & 6 \\
\hline Xestia xanthographa & & & 5.222 & 19.21 & & 11.51 & 9.58 & 6 \\
\hline Agrochola circellaris* & & 19.46 & 4.775 & 11.93 & & & 7.06 & 6 \\
\hline Hypsopygia costalis* & & 24.84 & 20.53 & & & & 6.06 & 4 \\
\hline Allophyes oxyacanthae & 10.58 & & & & 17.62 & & 4.59 & 6 \\
\hline Trachea atriplicis & 13.45 & & & & 12.57 & & 4.14 & 6 \\
\hline Mythimna albipuncta & 12.26 & 4.731 & 5.103 & & & & 3.99 & 6 \\
\hline Acronicta rumicis* & 5.067 & 6.882 & 6.625 & & & & 3.22 & 6 \\
\hline Tethea ocularis & & & & 6.299 & & 4.955 & 2.88 & 3 \\
\hline Agrotis segetum* & 5.923 & 5.269 & & & & & 2.80 & 6 \\
\hline Acronicta megacephala* & & & & 5.146 & & & 1.89 & 6 \\
\hline Pelosia muscerda & & & & & 16.36 & & 1.68 & 2 \\
\hline Agrochola helvola & & & & & & 6.087 & 1.29 & 5 \\
\hline Cirrhia icteritia & & & & & & 4.487 & 0.80 & 2 \\
\hline Thyatira batis* & & & & & 5.559 & & 0.74 & 4 \\
\hline Craniophora ligustri & & & & & 3.348 & & 0.31 & 2 \\
\hline
\end{tabular}

The number of harmful and potentially significant pest species was 32 in the samples. Most of them (20) belong to the Noctuidae family and there were 5 Erebidae, 2 Geometridae, 3 Pyralidae and 2 Thyatiridae species.

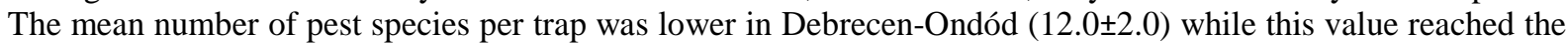
maximum in Hernádnémeti (17.6 \pm 1.1 ). The total number of pests was 5373 which was 31.3\% of all Lepidoptera samples. The ratio of the pest species was higher in the agricultural sites then in the most diverse ones. The mean proportion of Noctuidea was $74.6( \pm 18.2) \%$ and the Pyralidae was $18.1( \pm 19.1) \%$ while the other three family played a minor role. Baits lured the most individuals of Hypsopygia costalis, Agrochola circellaris, Acronicta rumicis, Agrotis segetum and Noctua pronuba. Most of them occurred at all of the studied sites, but the Hypsophygia costalis was caught only the agricultural sites. In Balmazújváros high abundance of Agrochola circellaris and Acronicta megacephala was caused by nearby poplar plantation. These plantations can be a source of these pests. Considerable part of the pest species could be found with low abundance and 8 of them occurred only in the two more diverse species rich sites (Table 4).

The traps caught 34 individuals of seven protected Noctuidae, one Erebidae and one Nymphalidae species in all of the six sampling sites. Six of them and 19 other species are interesting and valuable in faunistical aspect. They mostly belong to the Noctuidae family however there were two Erebidae and two Geometridae species. During the studies totally 411 individuals of these valuable species were sampled, which is $2.4 \%$ of the Lepidopteans identified at species level while the ratio of the protected Lepidopterans was only $0.2 \%$. In Balmazújváros protected species were not sampled and only one valuable species could be found, however the number of protected species was also low both in the species rich Nagycsere and Nagydobrony. The number of faunistically interesting and protected species was much lower in the agricultural sites (max. 7 species) than in the two semi natural ones (14 and 15 species). The number of valuable species was the highest in Nagycsere where 4 protected and 11 faunistically interesting species were trapped. The ratio of valuable individuals differed between 2.9-4.5\% by sites, but the ratio of protected species was lower than 1\% in each site (Table 5). 
List of the pest species caught in the six sampling sites in 2013-2014 with their number of individuals and ratio among all Sampled Lepidoptera and taxonomy. Species are arranged by decreasing number of individuals

\begin{tabular}{|c|c|c|c|c|c|c|c|c|}
\hline Family & & Forró & Ondód & $\begin{array}{l}\text { Hernád- } \\
\text { németi }\end{array}$ & $\begin{array}{c}\text { Balmaz- } \\
\text { újváros }\end{array}$ & $\begin{array}{c}\text { Nagy- } \\
\text { dobrony }\end{array}$ & $\begin{array}{l}\text { Nagy- } \\
\text { csere }\end{array}$ & Sum \\
\hline Noctuidae & Agrochola circellaris & 61 & 181 & 160 & 693 & 12 & 104 & 1211 \\
\hline Pyralidae & Hypsopygia costalis & 76 & 231 & 688 & 44 & 0 & 0 & 1039 \\
\hline Noctuidae & Acronicta rumicis & 148 & 64 & 222 & 68 & 16 & 34 & 552 \\
\hline Noctuidae & Agrotis segetum & 173 & 49 & 88 & 99 & 25 & 46 & 480 \\
\hline Noctuidae & Noctua pronuba & 29 & 29 & 102 & 95 & 17 & 103 & 375 \\
\hline Noctuidae & Acronicta megacephala & 1 & 2 & 9 & 299 & 3 & 11 & 325 \\
\hline Noctuidae & Lacanobia oleracea & 70 & 7 & 69 & 17 & 21 & 13 & 197 \\
\hline Noctuidae & Agrotis exclamationis & 40 & 1 & 10 & 1 & 32 & 48 & 132 \\
\hline Noctuidae & Xestia c-nigrum & 38 & 1 & 53 & 23 & 11 & 3 & 129 \\
\hline Thyatiridae & Thyatira batis & 0 & 0 & 20 & 2 & 88 & 17 & 127 \\
\hline Pyralidae & Ostrinia nubilalis & 0 & 3 & 50 & 71 & 0 & 0 & 124 \\
\hline Noctuidae & Agrotis ipsilon & 26 & 24 & 25 & 36 & 0 & 11 & 122 \\
\hline Noctuidae & Conistra vaccinii & 14 & 0 & 2 & 8 & 12 & 68 & 104 \\
\hline Noctuidae & Phlogophora meticulosa & 11 & 4 & 48 & 16 & 7 & 13 & 99 \\
\hline Noctuidae & Lacanobia suasa & 81 & 1 & 4 & 0 & 1 & 3 & 90 \\
\hline Noctuidae & Mamestra brassicae & 38 & 7 & 28 & 6 & 0 & 0 & 79 \\
\hline Pyralidae & Pyralis farinalis & 1 & 11 & 18 & 9 & 0 & 0 & 39 \\
\hline Thyatiridae & Habrosyne pyrithoides & 0 & 2 & 12 & 2 & 14 & 1 & 31 \\
\hline Noctuidae & Hadula trifolii & 9 & 1 & 13 & 1 & 0 & 0 & 24 \\
\hline Noctuidae & Helicoverpa armigera & 0 & 0 & 0 & 0 & 1 & 22 & 23 \\
\hline Noctuidae & Acronicta psi & 9 & 8 & 2 & 0 & 0 & 0 & 19 \\
\hline Erebidae & Euclidia glyphica & 15 & 1 & 0 & 0 & 0 & 0 & 16 \\
\hline Noctuidae & Cosmia trapezina & 4 & 1 & 0 & 0 & 5 & 4 & 14 \\
\hline Erebidae & Scoliopteryx libatrix & 0 & 1 & 0 & 0 & 11 & 0 & 12 \\
\hline Erebidae & Phragmatobia fuliginosa & 0 & 0 & 0 & 0 & 0 & 3 & 3 \\
\hline Erebidae & Lymantria dispar & 0 & 0 & 0 & 0 & 0 & 1 & 1 \\
\hline Erebidae & Lymantria monacha & 0 & 0 & 0 & 0 & 0 & 1 & 1 \\
\hline Geometridae & Ectropis crepuscularia & 0 & 0 & 0 & 0 & 0 & 1 & 1 \\
\hline Geometridae & Peribatodes rhomboidaria & 0 & 0 & 0 & 0 & 0 & 1 & 1 \\
\hline Noctuidae & Colocasia coryli & 0 & 0 & 0 & 0 & 0 & 1 & 1 \\
\hline Noctuidae & Autographa gamma & 0 & 0 & 0 & 0 & 0 & 1 & 1 \\
\hline Noctuidae & Macdunnoughia confusa & 0 & 0 & 0 & 0 & 0 & 1 & 1 \\
\hline \multicolumn{2}{|c|}{ Total number of pests } & 844 & 629 & 1623 & 1490 & 276 & 511 & 5373 \\
\hline \multicolumn{2}{|c|}{ Ratio of pests among all Lepidoptera (\%) } & 28.9 & 67.6 & 48.4 & 25.6 & 17.5 & 20.0 & 31.3 \\
\hline \multicolumn{2}{|c|}{ Total number of identified Lepidoptera } & 2921 & 930 & 3351 & 5810 & 1583 & 2563 & 17158 \\
\hline
\end{tabular}

Semi-synthetic baits used in this study attract a large amount of Noctuid moths. Both the species number and abundance were high in each sampling sites, although they depend on the landscape structure. High landscape diversity results in higher species richness but in case of abundance it does not cause differences. The bait also lured Vespidae species with relatively high abundance, but did not attract honey-bees. Most of the sampled Lepidopterans belonged to the Noctuidae family (totally 124 species). Among them the species of Noctuidne, Xyleninae and Hadeninae subfamilies were the most abundant. Beyond them the species number of Erebidae and Geometridae families was the highest. Among the most abundant species there were six pests: Agrochola circellaris, Hypsopygia costalis, Acronicta rumicis, Agrotis segetum, Acronicta megacephala and Thyatiria batis. The dominant species of arable land and more diverse sites were different. The total number of pest species was 32. Most of them (20) were noctuid moths containing such harmful ones as Agrotis segetum, Agrotis exclamationis, Agrotis ipsilon, Lacanobia oleracea etc.. The summarised proportion of these species was 31.3\% among all identified Lepidopterans. Considering their economic importance the majority of the caught Lepidopterans were indifferent. Both number and abundance of protected and valuable species was low, however the risk of catching valuable and non-target species was higher in the natural and semi natural sites. The traps caught totally 411 individuals of 28 protected and/or faunistically interesting species, which was a very little part (2.4\%) of all sampled Lepidopterans.

On the basis of these preliminary results the use of the tested semi-synthetic bait does not endanger the populations of non-target Lepidopterans. For more detailed results we should carry out further studies and should analyse these and other ongoing studies together. 
List of the protected and faunistically interesting species caught in the six sampling sites in 2013-2014 with their number of individuals and ratio among all sampled Lepidoptera and taxonomy. P: protected, F: faunistically interesting

\begin{tabular}{|c|c|c|c|c|c|c|c|c|c|}
\hline Prot. & Family & & Forró & Ondód & $\begin{array}{l}\text { Hernád- } \\
\text { németi }\end{array}$ & $\begin{array}{l}\text { Balmaz- } \\
\text { újváros }\end{array}$ & $\begin{array}{c}\text { Nagy- } \\
\text { dobrony }\end{array}$ & $\begin{array}{l}\text { Nagy- } \\
\text { csere }\end{array}$ & Sum \\
\hline $\mathrm{P} / \mathrm{F}$ & Noctuidae & Enargia paleacea & 0 & 0 & 0 & 0 & 1 & 5 & 6 \\
\hline $\mathrm{P} / \mathrm{F}$ & Noctuidae & Mormo maura & 0 & 0 & 0 & 0 & 3 & 0 & 3 \\
\hline $\mathrm{P} / \mathrm{F}$ & Noctuidae & Orbona fragariae & 4 & 0 & 0 & 0 & 0 & 1 & 5 \\
\hline $\mathrm{P} / \mathrm{F}$ & Noctuidae & Staurophora celsia & 0 & 0 & 0 & 0 & 0 & 9 & 9 \\
\hline $\mathrm{P}$ & Nymphalidae & Apatura ilia & 0 & 0 & 0 & 0 & 2 & 0 & 2 \\
\hline $\mathrm{F}$ & Erebidae & Catocala hymenaea & 0 & 1 & 75 & 0 & 0 & 0 & 76 \\
\hline $\mathrm{F}$ & Erebidae & Herminia tenuialis & 0 & 0 & 0 & 0 & 0 & 1 & 1 \\
\hline $\mathrm{F}$ & Geometridae & Euphya unangulata & 0 & 0 & 0 & 0 & 2 & 0 & 2 \\
\hline $\mathrm{F}$ & Geometridae & Idaea muricata & 0 & 0 & 0 & 0 & 0 & 14 & 14 \\
\hline $\mathrm{F}$ & Noctuidae & Xestia castanea & 0 & 0 & 0 & 0 & 2 & 0 & 2 \\
\hline $\mathrm{F}$ & Noctuidae & Xestia sexstrigata & 0 & 0 & 0 & 0 & 2 & 2 & 4 \\
\hline $\mathrm{F}$ & Noctuidae & Agrochola humilis & 3 & 3 & 2 & 0 & 0 & 8 & 16 \\
\hline $\mathrm{F}$ & Noctuidae & Agrochola laevis & 3 & 9 & 2 & 0 & 0 & 34 & 48 \\
\hline $\mathrm{F}$ & Noctuidae & Agrochola lota & 0 & 0 & 1 & 0 & 33 & 0 & 34 \\
\hline $\mathrm{F}$ & Noctuidae & Atethmia centrago & 0 & 0 & 0 & 0 & 4 & 0 & 4 \\
\hline $\mathrm{F}$ & Noctuidae & Blepharita satura & 0 & 0 & 0 & 0 & 0 & 1 & 1 \\
\hline $\mathrm{F}$ & Noctuidae & Dryobotodes eremita & 45 & 7 & 14 & 0 & 0 & 0 & 66 \\
\hline $\mathrm{F}$ & Noctuidae & Helotropha leucostigma & 0 & 0 & 0 & 0 & 0 & 1 & 1 \\
\hline $\mathrm{F}$ & Noctuidae & Tiliacea citrago & 0 & 0 & 0 & 0 & 1 & 0 & 1 \\
\hline $\mathrm{F}$ & Noctuidae & Xylena exsoleta & 5 & 3 & 20 & 14 & 0 & 12 & 54 \\
\hline \multicolumn{3}{|c|}{ Number of valuable species } & 7 & 7 & 7 & 1 & 14 & 15 & 28 \\
\hline
\end{tabular}

\section{ACKNOWLEDGEMENT}

Szabolcs Szanyi was supported by the Collegium Talentum grant of the Edutus High School.

\section{REFERENCES}

Chreighton, C. S.-Mcfadden, T. L.-Cuthbert, E. R. (1973): Supplementary data on phenylacetaldehyde: an attractant for lepidoptera. Cantelo, W. W.-Jacobson, M. (1979): Phenylacetaldehyde attracts moths to bladder flower and blacklight traps. Environmental Entomology 8:444-447.

Jermy, T.-Balázs, K. (1993): A növényvédelmi állattan kézikönyve 4/A-B. Akadémiai Kiadó, Budapest. 830 p.

Kádár, M.-Petrányi, G.-Ronkay G.-Ronkay, L. (2010): A magyarországi bagolylepkék (Lepidoptera, Noctuidae) fényképes határozója. (Photographic identification guide to the noctuids (Lepidoptera, Noctuidae) of Hungary). Szalkay József Magyar Lepkészeti Egyesület. Budapest.

KÖM (2001): 13/2001. (V. 9.) KöM rendelet a védett és a fokozottan védett növény- és állatfajokról, a fokozottan védett barlangok köréröl, valamint az Európai Közösségben természetvédelmi szempontból jelentős növény- és állatfajok közzétételéről.

Landolt, P. J.(2000): New chemical attractants for trapping Lacanobia subjuncta, Mamestra configurata, and Xestia c-nigrum (Lepidoptera: Noctuidae). Journal of Economical Entomology 93: 101-106.

Landolt, P. J.-Alfaro, J. F. (2001): Trapping Lacanobia subjuncta, Xestia c-nigrum and Mamestra configurata (Lepidoptera: Noctuidae) with acetic acid and 3-methyl-1-butanol in controlled relesase dispensers. Environmental Entomology 30: 656-662.

Mészáros Z.-Szabóky, Cs. (2012): A magyarországi nagylepkék gyakorlati albuma. Szalkay József Magyar Lepkészeti Egyesület. Budapest, 185 pp.

Nagy, A.-Szarukán, I.-Gém, F.-Nyitrai, R.-Tóth, M. (2014): Vizsgálatok bagolylepkék (Lepidoptera: Noctuidae) fogására kifejlesztett szintetikus illatanyag csalétkek hatékonyságának növelésére. Agrártudományi Közlemények (Acta Agraria Dedreceniensis) 2014/62: 86-91. Olenici, N.-Capuse, I.-Olenici, V.-Oprean, I.-Mihalciuc, V. (2007): Non-target Lepidopteran species in pheromone traps baited with attractants for several Tortricid moths. Annalele ICAS 50: 185-201.

Szabóky, Cs.-Leskó, K. (1999): Lepidoptera - lepkék. 354 - 409. In: Tóth, J. (Ed.): Erdészeti rovartan. Agroinform kiadó. Budapest. Tóth, J. (1999): Erdészeti rovartan. Agroinform Kiadó, Budapest. 480 p. 
Tóth, M.-Szarukán, I.-Dorogi B.-Gulyás, A.-Nagy, P.-Rozgonyi, Z. (2010): Male and female Noctuid moths attracted to synthetic lures in Europe. Journal of Chemical Ecology 36: 592-598.

Tóth, M.-Szarukán, I.-Nagy, A.-Gém, F.-Nyitrai, R.-Kecskés, Zs.-Krakkó, L.-Jósvai, J. K.-Bélai, I. (2015): Félszintetikus “biszex” csalétkek kártevő rovarok nőstényeinek és hímjeinek fogására. Növényvédelem 51(5): 197-205.

Varga, Z. (2011): Magyarország nagylepkéi - Macrolepidoptera of Hungary. Heterocera Press, Budapest, 354 p.

\section{Appendix 1}

List of the sampled Lepidoptera species with their taxonoamy and conservational status. Pest species are signed with asterix $\left({ }^{*}\right)$. P: protescted, F: faunistically interesting

\begin{tabular}{|c|c|c|c|c|}
\hline & & Family & Subfamily & Species \\
\hline & & Hepialidae & & one unidentified species \\
\hline & $*$ & Pyralidae & Pyralinae & Hypsopygia costalis (Fabricius 1775) \\
\hline & $*$ & Pyralidae & Pyralinae & Pyralis farinalis (Linnaeus, 1758) \\
\hline & $*$ & Pyralidae & Pyraustinae & Ostrinia nubilalis (Hübner, 1796) \\
\hline \multirow[t]{17}{*}{$\mathrm{P}$} & & Nymphalidae & Apaturinae & Apatura ilia ([Denis \& Schiff ermüller], 1775) \\
\hline & & Nymphalidae & Nymphalinae & Araschnia levana (Linnaeus, 1758) \\
\hline & & Nymphalidae & Nymphalinae & Nymphalis c-album (Linnaeus, 1758) \\
\hline & & Nymphalidae & Satyrinae & Minois dryas (Scopoli, 1763) \\
\hline & & Nymphalidae & Satyrinae & Pararge aegeria tircis (Godart, 1821) \\
\hline & & Sphingidae & Macroglossinae & Deilephila porcellus (Linnaeus, 1758) \\
\hline & & Geometridae & Ennominae & Apeira syringaria (Linnaeus, 1758) \\
\hline & & Geometridae & Ennominae & Cabera exanthemata (Scopoli, 1763) \\
\hline & $*$ & Geometridae & Ennominae & Ectropis crepuscularia ([Denis et Schiffermüller], 1775) \\
\hline & & Geometridae & Ennominae & Ematurga atomaria (Linnaeus, 1758) \\
\hline & & Geometridae & Ennominae & Hypomecis punctinalis (Scopoli, 1763) \\
\hline & & Geometridae & Ennominae & Hypomecis roboraria ([Denis \& Schiffermüller], 1775) \\
\hline & & Geometridae & Ennominae & Ligdia adustata ([Denis \& Schiffermüller], 1775) \\
\hline & & Geometridae & Ennominae & Macaria notata (Linnaeus, 1758) \\
\hline & $*$ & Geometridae & Ennominae & Peribatodes rhomboidaria ([Denis \& Schiffermüller], 1775) \\
\hline & & Geometridae & Larentiinae & Cosmorhoe ocellata (Linnaeus, 1758) \\
\hline & & Geometridae & Larentiinae & Epirrita autumnata (Borkhausen, 1794) \\
\hline \multirow[t]{2}{*}{$\mathrm{F}$} & & Geometridae & Larentiinae & Euphya unangulata (Haworth, 1809) \\
\hline & & Geometridae & Sterrhinae & Idaea aversata (Linnaeus, 1758) \\
\hline \multirow[t]{13}{*}{$\mathrm{F}$} & & Geometridae & Sterrhinae & Idaea muricata (Hufnagel, 1787) \\
\hline & & Geometridae & Sterrhinae & Timandra comae (Schmidt, 1931) \\
\hline & $*$ & Thyatiridae & Thyatirinae & Habrosyne pyrithoides (Hufnagel, 1766) \\
\hline & & Thyatiridae & Thyatirinae & Tethea ocularis (Linnaeus, 1758) \\
\hline & & Thyatiridae & Thyatirinae & Tethea or ([Denis et Schiffermüller], 1775) \\
\hline & $*$ & Thyatiridae & Thyatirinae & Thyatira batis (Linnaeus, 1758) \\
\hline & & Nolidae & Nolinae & Nola cristatula (Hübner, 1793) \\
\hline & & Nolidae & Nolinae & Nycteola degenerana (Hübner, 1799) \\
\hline & $*$ & Erebidae & Arctiinae & Phragmatobia fuliginosa (Linnaeus, 1758) \\
\hline & & Erebidae & Aventiinae & Trisateles emortualis ([Denis \& Schiff ermüller], 1775) \\
\hline & $*$ & Erebidae & Calpinae & Scoliopteryx libatrix (Linnaeus, 1758) \\
\hline & & Erebidae & Catocalinae & Catocala electa (Vieweg, 1790) \\
\hline & & Erebidae & Catocalinae & Catocala elocata (Esper, 1788) \\
\hline \multirow[t]{2}{*}{$\mathrm{P}$} & & Erebidae & Catocalinae & Catocala fraxini (Linnaeus, 1758) \\
\hline & & Erebidae & Catocalinae & Catocala fulminea (Scopoli, 1763) \\
\hline \multirow[t]{11}{*}{$\mathrm{F}$} & & Erebidae & Catocalinae & Catocala hymenaea ([Denis \& Schiff ermüller], 1775) \\
\hline & & Erebidae & Catocalinae & Catocala nupta (Linnaeus, 1758) \\
\hline & & Erebidae & Catocalinae & Catocala promissa (Denis \& Schiffermüller, 1775) \\
\hline & & Erebidae & Catocalinae & Catocala sponsa (Linnaeus, 1767) \\
\hline & & Erebidae & Catocalinae & Dysgonia algira (Linnaeus, 1767) \\
\hline & $*$ & Erebidae & Catocalinae & Euclidia glyphica (Linnaeus, 1758) \\
\hline & & Erebidae & Catocalinae & Lygephila craccae ([Denis \& Schiff ermüller], 1775) \\
\hline & & Erebidae & Catocalinae & Lygephila pastinum (Treitschke, 1826) \\
\hline & & Erebidae & Eustrotiinae & Protodeltote pygarga (Hufnagel, 1766) \\
\hline & & Erebidae & Herminiinae & Herminia grisealis ([Denis \& Schiff ermüller], 1775) \\
\hline & & Erebidae & Herminiinae & Herminia tarsipennalis (Treitschke, 1835) \\
\hline \multirow[t]{9}{*}{$\mathrm{F}$} & & Erebidae & Herminiinae & Herminia tenuialis (Rebel,1899) \\
\hline & & Erebidae & Hypeninae & Hypena proboscidalis (Linnaeus, 1758) \\
\hline & & Erebidae & Hypeninae & Hypena rostralis (Linnaeus, 1758) \\
\hline & & Erebidae & Lithosiinae & Eilema griseola (Hübner, 1803) \\
\hline & & Erebidae & Lithosiinae & Lithosia quadra (Linnaeus, 1758) \\
\hline & & Erebidae & Lithosiinae & Pelosia muscerda (Hufnagel, 1766) \\
\hline & & Erebidae & Lithosiinae & Wittia sororcula (Hufnagel, 1766) \\
\hline & $*$ & Erebidae & Lymantriinae & Lymantria dispar Linnaeus, 1758 \\
\hline & $*$ & Erebidae & Lymantriinae & Lymantria monacha (Linnaeus, 1758) \\
\hline
\end{tabular}


Continuation of Appendix 1.

\begin{tabular}{|c|c|c|c|c|}
\hline & & Family & Subfamily & Species \\
\hline & & Noctuidae & Acontiinae & Aedia leucomelas (Linnaeus, 1758) \\
\hline & & Noctuidae & Acronictinae & Acronicta auricoma ([Denis \& Schiff ermüller], 1775) \\
\hline & & Noctuidae & Acronictinae & Acronicta euphorbiae ([Denis \& Schiff ermüller], 1775) \\
\hline & * & Noctuidae & Acronictinae & Acronicta megacephala ([Denis \& Schiff ermüller], 1775) \\
\hline & $*$ & Noctuidae & Acronictinae & Acronicta psi (Linnaeus, 1758) \\
\hline & $*$ & Noctuidae & Acronictinae & Acronicta rumicis (Linnaeus, 1758) \\
\hline & & Noctuidae & Acronictinae & Craniophora ligustri ([Denis \& Schiffermüller], 1775) \\
\hline & & Noctuidae & Acronictinae & Moma alpium (Osbeck, 1778) \\
\hline & & Noctuidae & Amphipyrinae & Amphipyra berbera svenssoni (Fletcher, 1968) \\
\hline & & Noctuidae & Amphipyrinae & Amphipyra livida ([Denis \& Schiff ermüller], 1775) \\
\hline & & Noctuidae & Amphipyrinae & Amphipyra pyramidea (Linnaeus, 1758) \\
\hline & & Noctuidae & Amphipyrinae & Amphipyra tragopoginis (Clerck, 1759) \\
\hline & & Noctuidae & Bryophilinae & Cryphia algae (Fabricius, 1775) \\
\hline $\mathrm{P}$ & & Noctuidae & Catocalinae & Catephia alchymista ([Denis \& Schiff ermüller], 1775) \\
\hline $\mathrm{F}$ & & Noctuidae & Condicinae & Eucarta amethystina (Hübner, 1803) \\
\hline \multirow[t]{25}{*}{$\mathrm{F}$} & & Noctuidae & Condicinae & Eucarta virgo (Treitschke, 1825) \\
\hline & & Noctuidae & Cryphiinae & Globia algae (Esper, 1789) \\
\hline & & Noctuidae & Ctenuchinae & Amata phegea (Linnaeus, 1758) \\
\hline & & Noctuidae & Hadeninae & Hada plebeja (Linnaeus, 1761) \\
\hline & $*$ & Noctuidae & Hadeninae & Hadula trifolii (Hufnagel, 1766) \\
\hline & & Noctuidae & Hadeninae & Lacanobia contigua ([Denis \& Schiff ermüller], 1775) \\
\hline & $*$ & Noctuidae & Hadeninae & Lacanobia oleracea (Linnaeus, 1758) \\
\hline & $*$ & Noctuidae & Hadeninae & Lacanobia suasa ([Denis \& Schiffermüller], 1775) \\
\hline & & Noctuidae & Hadeninae & Lacanobia thalassina (Hufnagel, 1766) \\
\hline & & Noctuidae & Hadeninae & Lacanobia w-latinum (Hufnagel, 1766) \\
\hline & & Noctuidae & Hadeninae & Leucania obsoleta (Hübner 1803) \\
\hline & $*$ & Noctuidae & Hadeninae & Mamestra brassicae (Linnaeus, 1758) \\
\hline & & Noctuidae & Hadeninae & Mythimna (Mythimna) pallens (Linnaeus, 1758) \\
\hline & & Noctuidae & Hadeninae & Mythimna albipuncta ([Denis et Schiffermüller], 1775) \\
\hline & & Noctuidae & Hadeninae & Mythimna ferrago (Fabricius, 1787) \\
\hline & & Noctuidae & Hadeninae & Mythimna l-album (Linnaeus, 1767) \\
\hline & & Noctuidae & Hadeninae & Mythimna turca (Linnaeus, 1761) \\
\hline & & Noctuidae & Hadeninae & Mythimna vitellina (Hübner, 1808) \\
\hline & & Noctuidae & Hadeninae & Tholera cespitis ([Denis \& Schiffermüller], 1775) \\
\hline & $*$ & Noctuidae & Heliothinae & Helicoverpa armigera (Hübner, 1808) \\
\hline & & Noctuidae & Heliothinae & Pyrrhia umbra (Hufnagel, 1766) \\
\hline & $*$ & Noctuidae & Noctuinae & Agrotis exclamationis (Linnaeus, 1758) \\
\hline & $*$ & Noctuidae & Noctuinae & Agrotis ipsilon (Hufnagel, 1766) \\
\hline & $*$ & Noctuidae & Noctuinae & Agrotis segetum ([Denis et Schiffermüller], 1775) \\
\hline & & Noctuidae & Noctuinae & Axylia putris (Linnaeus, 1761) \\
\hline $\mathrm{F}$ & & Noctuidae & Noctuinae & Diarsia rubi (Vieweg, 1790) \\
\hline \multirow[t]{11}{*}{$\mathrm{F}$} & & Noctuidae & Noctuinae & Euxoa segnilis (Duponchel, 1837) \\
\hline & & Noctuidae & Noctuinae & Metagnorisma depuncta (Linnaeus, 1761) \\
\hline & & Noctuidae & Noctuinae & Noctua fimbriata (Schreber, 1759) \\
\hline & & Noctuidae & Noctuinae & Noctua interjecta Hübner, 1803 \\
\hline & & Noctuidae & Noctuinae & Noctua interposita (Hübner, 1790) \\
\hline & & Noctuidae & Noctuinae & Noctua janthe (Borkhausen, 1792) \\
\hline & & Noctuidae & Noctuinae & Noctua janthina ([Denis \& Schiffermüller], 1775) \\
\hline & & Noctuidae & Noctuinae & Noctua orbona (Hufnagel, 1766) \\
\hline & $*$ & Noctuidae & Noctuinae & Noctua pronuba (Linnaeus, 1758) \\
\hline & & Noctuidae & Noctuinae & Ochropleura plecta (Linnaeus, 1761) \\
\hline & & Noctuidae & Noctuinae & Xestia baja ([Denis \& Schiffermüller], 1775) \\
\hline \multirow[t]{2}{*}{$\mathrm{F}$} & & Noctuidae & Noctuinae & Xestia castanea (Esper, 1798) \\
\hline & $*$ & Noctuidae & Noctuinae & Xestia c-nigrum (Linnaeus, 1758) \\
\hline \multirow[t]{7}{*}{$\mathrm{F}$} & & Noctuidae & Noctuinae & Xestia sexstrigata (Haworth, 1809) \\
\hline & & Noctuidae & Noctuinae & Xestia xanthographa ([Denis \& Schiff ermüller], 1775) \\
\hline & & Noctuidae & Oncocnemidinae & Calophasia lunula (Hufnagel, 1766) \\
\hline & $*$ & Noctuidae & Pantheinae & Colocasia coryli (Linnaeus, 1758) \\
\hline & $*$ & Noctuidae & Plusiinae & Autographa gamma (Linnaeus, 1758) \\
\hline & $*$ & Noctuidae & Plusiinae & Macdunnoughia confusa (Stephens, 1850) \\
\hline & & Noctuidae & Psaphidinae & Allophyes oxyacanthae (Linnaeus, 1758) \\
\hline \multirow[t]{5}{*}{$\mathrm{P} / \mathrm{F}$} & & Noctuidae & Psaphidinae & Meganephria bimaculosa (Linnaeus, 1767) \\
\hline & & Noctuidae & Rivulinae & Rivula sericealis (Scopoli, 1763) \\
\hline & & Noctuidae & Xyleninae & Actinotia polyodon (Clerck, 1759) \\
\hline & $*$ & Noctuidae & Xyleninae & Agrochola circellaris (Hufnagel, 1766) \\
\hline & & Noctuidae & Xyleninae & Agrochola helvola (Linnaeus, 1758) \\
\hline $\mathrm{F}$ & & Noctuidae & Xyleninae & Agrochola humilis ([Denis \& Schiff ermüller], 1775) \\
\hline \multirow[t]{2}{*}{$\mathrm{F}$} & & Noctuidae & Xyleninae & Agrochola laevis (Hübner, 1803) \\
\hline & & Noctuidae & Xyleninae & Agrochola litura (Linnaeus, 1758) \\
\hline \multirow[t]{4}{*}{$\mathrm{F}$} & & Noctuidae & Xyleninae & Agrochola lota (Clerck, 1759) \\
\hline & & Noctuidae & Xyleninae & Agrochola lychnidis ([Denis \& Schiff ermüller], 1775) \\
\hline & & Noctuidae & Xyleninae & Agrochola macilenta (Hübner, 1803) \\
\hline & & Noctuidae & Xyleninae & Agrochola nitida ([Denis et Schiffermüller], 1775) \\
\hline
\end{tabular}


Continuation of Appendix 1.

\begin{tabular}{|c|c|c|c|c|}
\hline & & Family & Subfamily & Species \\
\hline \multirow{8}{*}{\multicolumn{2}{|c|}{$\mathrm{F}$}} & Noctuidae & Xyleninae & Ammoconia caecimacula ([Denis \& Schiff ermüller], 1775) \\
\hline & & Noctuidae & Xyleninae & Apamea anceps ([Denis \& Schiff ermüller], 1775) \\
\hline & & Noctuidae & Xyleninae & Apamea lithoxylaea ([Denis \& Schiffermüller], 1775) \\
\hline & & Noctuidae & Xyleninae & Apamea monoglypha (Hufnagel, 1766) \\
\hline & & Noctuidae & Xyleninae & Aporophyla lutulenta ([Denis \& Schiff ermüller], 1775) \\
\hline & & Noctuidae & Xyleninae & Atethmia centrago (Haworth, 1809) \\
\hline & & Noctuidae & Xyleninae & Athetis furvula (Hübner, 1808) \\
\hline & & Noctuidae & Xyleninae & Athetis gluteosa (Treitschke, 1835) \\
\hline $\mathrm{F}$ & & Noctuidae & Xyleninae & Blepharita satura ([Denis \& Schiff ermüller], 1775) \\
\hline \multirow[t]{14}{*}{$\mathrm{F}$} & & Noctuidae & Xyleninae & Brachylomia viminalis (Fabricius, 1777) \\
\hline & & Noctuidae & Xyleninae & Caradrina clavipalpis (Scopoli, 1763) \\
\hline & & Noctuidae & Xyleninae & Caradrina kadenii Freyer, 1836 \\
\hline & & Noctuidae & Xyleninae & Caradrina morpheus (Hufnagel, 1766) \\
\hline & & Noctuidae & Xyleninae & Cirrhia gilvago ([Denis \& Schiff ermüller], 1775) \\
\hline & & Noctuidae & Xyleninae & Cirrhia icteritia (Hufnagel, 1766) \\
\hline & & Noctuidae & Xyleninae & Cirrhia ocellaris (Borkhausen, 1792) \\
\hline & & Noctuidae & Xyleninae & Conistra erythrocephala ([Denis \& Schiff ermüller], 1775) \\
\hline & & Noctuidae & Xyleninae & Conistra ligula (Esper, 1791) \\
\hline & & Noctuidae & Xyleninae & Conistra rubiginosa (Scopoli, 1763) \\
\hline & $*$ & Noctuidae & Xyleninae & Conistra vaccinii (Linnaeus, 1761) \\
\hline & & Noctuidae & Xyleninae & Conistra veronicae (Hübner, 1813) \\
\hline & & Noctuidae & Xyleninae & Cosmia affinis (Linnaeus, 1767) \\
\hline & $*$ & Noctuidae & Xyleninae & Cosmia trapezina (Linnaeus, 1758) \\
\hline \multirow[t]{2}{*}{ F } & & Noctuidae & Xyleninae & Dryobotodes eremita (Fabricius, 1775) \\
\hline & & Noctuidae & Xyleninae & Dypterygia scabriuscula (Linnaeus, 1758) \\
\hline \multirow[t]{4}{*}{$\mathrm{P} / \mathrm{F}$} & & Noctuidae & Xyleninae & Enargia paleacea (Esper, 1788) \\
\hline & & Noctuidae & Xyleninae & Euplexia lucipara (Linnaeus, 1758) \\
\hline & & Noctuidae & Xyleninae & Eupsilia transversa (Hufnagel, 1766) \\
\hline & & Noctuidae & Xyleninae & Griposia aprilina (Linnaeus, 1758) \\
\hline \multirow[t]{4}{*}{$\mathrm{F}$} & & Noctuidae & Xyleninae & Helotropha leucostigma (Hübner, [1808]) \\
\hline & & Noctuidae & Xyleninae & Hoplodrina ambigua ([Denis \& Schiffermüller, 1775]) \\
\hline & & Noctuidae & Xyleninae & Hoplodrina blanda ([Denis \& Schiffermüller, 1775]) \\
\hline & & Noctuidae & Xyleninae & Lithophane ornithopus (Hufnagel, 1766) \\
\hline \multirow[t]{5}{*}{$\mathrm{P} / \mathrm{F}$} & & Noctuidae & Xyleninae & Lithophane semibrunnea (Haworth, 1809) \\
\hline & & Noctuidae & Xyleninae & Mesapamea secalella Remm, 1983 \\
\hline & & Noctuidae & Xyleninae & Mesapamea secalis (Linnaeus, 1758) \\
\hline & & Noctuidae & Xyleninae & Mesogona acetosellae ([Denis \& Schiff ermüller], 1775) \\
\hline & & Noctuidae & Xyleninae & Mesoligia furuncula ([Denis \& Schiff ermüller], 1775) \\
\hline \multirow[t]{3}{*}{$\mathrm{P} / \mathrm{F}$} & & Noctuidae & Xyleninae & Mormo maura (Linnaeus, 1758) \\
\hline & & Noctuidae & Xyleninae & Oligia latruncula ([Denis \& Schiff ermüller], 1775) \\
\hline & & Noctuidae & Xyleninae & Oligia strigilis (Linnaeus, 1758) \\
\hline \multirow[t]{5}{*}{$\mathrm{P} / \mathrm{F}$} & & Noctuidae & Xyleninae & Orbona fragariae (Vieweg, 1790) \\
\hline & & Noctuidae & Xyleninae & Parastichtis suspecta (Hübner, 1817) \\
\hline & $*$ & Noctuidae & Xyleninae & Phlogophora meticulosa (Linnaeus, 1758) \\
\hline & & Noctuidae & Xyleninae & Pseudeustrotia candidula ([Denis et Schiffermüller], 1775) \\
\hline & & Noctuidae & Xyleninae & Rusina ferruginea (Esper, 1785) \\
\hline \multirow[t]{3}{*}{$\mathrm{P} / \mathrm{F}$} & & Noctuidae & Xyleninae & Staurophora celsia (Linnaeus, 1758) \\
\hline & & Noctuidae & Xyleninae & Thalpophila matura (Hufnagel, 1766) \\
\hline & & Noctuidae & Xyleninae & Tiliacea aurago (Denis \& Schiffermüller, 1775) \\
\hline \multirow[t]{6}{*}{$\mathrm{F}$} & & Noctuidae & Xyleninae & Tiliacea citrago (Linnaeus, 1758) \\
\hline & & Noctuidae & Xyleninae & Trachea atriplicis (Linnaeus, 1758) \\
\hline & & Noctuidae & Xyleninae & Xanthia gilvago ([Denis \& Schiff ermüller], 1775) \\
\hline & & Noctuidae & Xyleninae & Xanthia icteritia (Hufnagel, 1766) \\
\hline & & Noctuidae & Xyleninae & Xanthia ocellaris (Borkhausen, 1792) \\
\hline & & Noctuidae & Xyleninae & Xanthia togata (Esper, 1788) \\
\hline $\mathrm{F}$ & & Noctuidae & Xyleninae & Xylena exsoleta (Linnaeus, 1758) \\
\hline
\end{tabular}

